Research Note

\title{
The Impact of Human Resources on Innovation Activities in the Baltic States: Employment and Innovation Persistence
}

Bahman Peyravi

Corresponding author: bahman.peyravi@vgtu.lt

Vilnius Gediminas Technical University

Vilnius, Lithuania

\section{About the author}

Bahman Peyravi obtained his bachelor's degree in mechanical engineering at the Faculty of Mechanics of Yildiz Technical University, his master degree in Industrial Engineering and Innovation Management at the Faculty of Mechanics at Vilnius Gediminas Technical University, Lithuania. He presented his Ph.D dissertation at the same university and focuses on research within the field of industrial engineering and innovation.

\section{Abstract}

This paper examines the nexus between human resources and persistency in innovation activities (product and process innovation) in the Baltic States (Lithuania, Latvia and Estonia). The paper builds a conceptual framework which links success and failure in innovation activities and the role of human resources in it. The research grounded on personal interpretation is based on literature review and recent social and economic growth indicators on the Baltic States. The research finding emphasizes on the urgent needs and necessity of human resources (HR) flow from either EU member countries or third countries (non-EU members) to the Baltic States.

Keywords: Innovation, Human resources, Innovation activities, Product innovation, Process innovation 


\section{Introduction}

At the last two decades, especially after the global financial crisis in late 1990s and 2008, unemployment and job creation became extremely important for the policy-makers globally. Taking a look at the Baltic States as the EU member states, the Europe 2020 strategy was the main force for job creation, so called "employment package". However, the effectiveness and efficiency of the package is under discussion in the mentioned states. A recent policy report (Eurostat, 2015) emphasized on the strong linkage between investments in R\&D activities, quality of innovative products and services and job creation. Based on the mentioned arguments, Bianchini and Pallegrino (2017) have mentioned that "...Statements of this kind, of course, recall endogenous growth models in which the accumulation of $R \& D$ and human capital is considered the primary source of long-term economic growth. The links between innovation and employment at the firmlevel are, however, far from straightforward" in their paper entitled "Innovation Persistence and Employment Dynamics".

The theoretical studies on the relationship between innovation and employment are still underdeveloped in some respects. This paper aims to elaborate various theoretical and statistical approaches on this matter in order to provide more concrete understanding for the Baltic States policy-makers to highlight the significant linkage between HR and innovation activities. The research grounded on personal interpretation is based on literature review and recent social and economic growth indicators on the Baltic States. The object of the paper is to highlight the impact of the human resources on innovation activities in the Baltic States. Presentation of literature review which links innovation to job creation and statistical analysis innovation performance of the Baltic States are the main objectives of this research.

\section{Literature Review}

In last two decades, many researches on linking human resources, job creation and innovation activities emerged - for instance, a significant work of Antonelli in 1997 entitled "The Economics of Path-Dependence in Industrial Organization", which emphasized on key priorities of innovation process and its persistency. "Initial Conditions and Moment Restrictions in Dynamic Panel Data Models" by Blundell et al. from 1998, presented significant evidences on the importance of innovation activities and job creation in developing economies. Moreover, many authors were taking innovation activities in the core of job creation, such as Malerba 2007, "Innovation and the Dynamics and Evolution of Industries: Progress and Challenges"; Vivarelli 2014, "Innovation, Employment and Skills in Advanced and Developing Countries: A Survey of Economic Literature"; and Dosi \& Nelson 2010, "Technical Change and Industrial Dynamics as Evolutionary Processes". The main focus points of the mentioned studies were policy priorities related to the innovation activities and job creation.

The studies mentioned above are mostly focusing on the persistence in innovative activities of firms (firmlevel). According to Dosi et al., 2008, firms are experiencing innovation process with their knowledge stocks 
and innovation capabilities. This approach is highly dependent and highly qualified as a technical tool. R\&D personnel brings success to innovation activities. Most studies are relying on the output of innovation activities predominantly targeting the number of patents, sales of innovative products and the development of product or process innovations (Cefis, 2003; Raymond et al., 2010 and Antonelli et al., 2012). Therefore, taking a look on any Baltic States neighbor country, for instance Finland which is regarded as the successful country in innovation activities, Deschryvere (2014) indicates that the relationship between R\&D and sales growth is more solid compared to occasional innovators between Finnish firms in a study entitled "R\&D, Firm Growth and the Role of Innovation Persistence: An Analysis of Finnish SMEs and Large Firms". This study presents significant evidence on the links between innovation persistence, job creation and sales growth. Based on the mentioned argument, Bianchini et al. (2017) argues as follows:

-. firms introducing new products on the market stimulate consumption and create new demand, thus allowing additional jobs to emerge. Less intuitively, however, there might also be an indirect negative effect: if new products substitute existing ones and the production of the new generation of products requires fewer workers than the production of the old products this might hinder employment (so-called "cannibalization"). Similar arguments apply in the case of process innovation. Firms may change their production process to improve the productivity of inputs, including labor. Thus, the negative effect of process innovation occurs when a firm can produce the same level of output with fewer workers.

Not only innovations are important for job creations, but also human resources are important for innovation process which can be defined as human, social and creative capital in innovation. Human factors and, in particular, education, knowledge and experience are considered key components of successful innovation today, since the human element is involved in the whole innovation process. In recent years, scholars have shown a growing interest in the role of human resources in stimulating organizational innovation performance (e.g. De Leede \& Looise, 2005; Beugelsdijk, 2008; Chen \& Huang, 2009; De Winne \& Sels, 2010). Innovation process and the performance can be studied under the notions of exploration and exploitation (March, 1991; Gupta et al., 2006). Exploration involves searching for new knowledge, technologies and products, whereas exploitation is about using and refining existing knowledge, technologies and products (Li et al., 2008). According to Nonaka et al. (1995), knowledge, skills, attitudes and other characteristics play a critical role in innovation. This approach can be distinguished in three main concepts: human, social and creative capital. On the firm-level, human capital is "the aggregate accumulation of individual human capital that can be combined in a way that creates value for the unit" (Wright \& McMahan, 2011). The concept of social capital is often used to highlight the potential benefit for innovation of interactions through relationships (Laursen et al., 2012). Innovation is rarely formed in isolated environment and often occurs with trust, shared knowledge, and other elements linked to group processes. The concept of creative capital was introduced in 2002 ; Florida (2004) expresses the concept as "why some places are better able to develop, attract, and retain human capital/skills/creative capabilities". All mentioned concepts need strong policy-making capability and implementation in order to create strong linkage between human resources and innovation activities.

Persistence in job creation is withal significant for policy-makers since such growth can be seen as a relief of economies to sustain employment and value creation in the long-term, and allow the early identification of 
firms with high growth potential. The main focus of most policy actions is that not only are firms expected to generate new jobs, but they are expected to do so over a number of consecutive years.

In the management field, a host of variables has been identified as an influencing organizational innovation:

- Having a vision of what the organization wishes to be;

- Searching for opportunities, experience and technological potential;

- Following market orientation;

- Market evolution and segmentation and the promotion and management of creative resources (Dalota and Perju, 2010).

Before the second contribution of this study, therefore, to provide an empirical validation to this second set of conjectures, it is important to emphasize on some important indicators. Since 2014, unemployment in Lithuania scored around 8\%, in Latvia dropped from $12 \%$ to $7 \%$, and Estonia was around $5 \%$ (www.tradingeconomics.com). However, youth unemployment rate in 2018 was recorded as $20 \%$ in Estonia, $10 \%$ in Lithuania and $10 \%$ in Latvia. Furthermore, another important indicator which must be taken into account is net migration rate. For instance, based on the data provided by Statistics Lithuania, from 2004 almost 619,000 residents left Lithuania, which means approximately 45,000 annual emigrations and only 194,000 people have arrived in 14 years. Mentioned indicators are the departing point of the study which contributes to the innovation activities, human resources and economic development.

\section{Statistical Review}

This study attempts to draw attention on statistical data which is based on the innovation performance of the Baltic States and its nexus with human resources and job creation. The study is based on European innovation scoreboard results, published in 2018. In the case of Lithuania, some increment in innovation performance is observed relative to the 2010 report. Lithuania has moved from a modest innovator to the level of moderate innovator. In recent years, achievement of marketing innovators and sales share new product innovators cannot be neglected, however, failure in non-R\&D innovation expenditure and least improvement in SMEs innovation in-house, product, process innovation and innovative SMEs collaboration is the point of departure which is the lowest score among the Baltic States. In Latvia, innovation performance and high collaboration between innovative SMEs are scored and the least improvement occurs in marketing innovators which moved Latvia from the modest level to the moderate level (Figure 1).

Estonia has the highest performance among the Baltic States. The main point behind a successful innovator is the strong cohesion between Estonia and Finland. This approach is emphasized in the OECD Regional Development Working Paper (2013) as: "Knowledge actors in the whole of Estonia - and especially in Tartu - can benefit from interactions with their Finnish neighbors. The fact that innovation policy is designed and implemented at the national level in Estonia, together with the small size of the country, also makes it more relevant to include all innovation system actors in the cross-border partnership", and furthermore: "Combining the strengths of Helsinki in science and technology, and the assets of Estonia as 


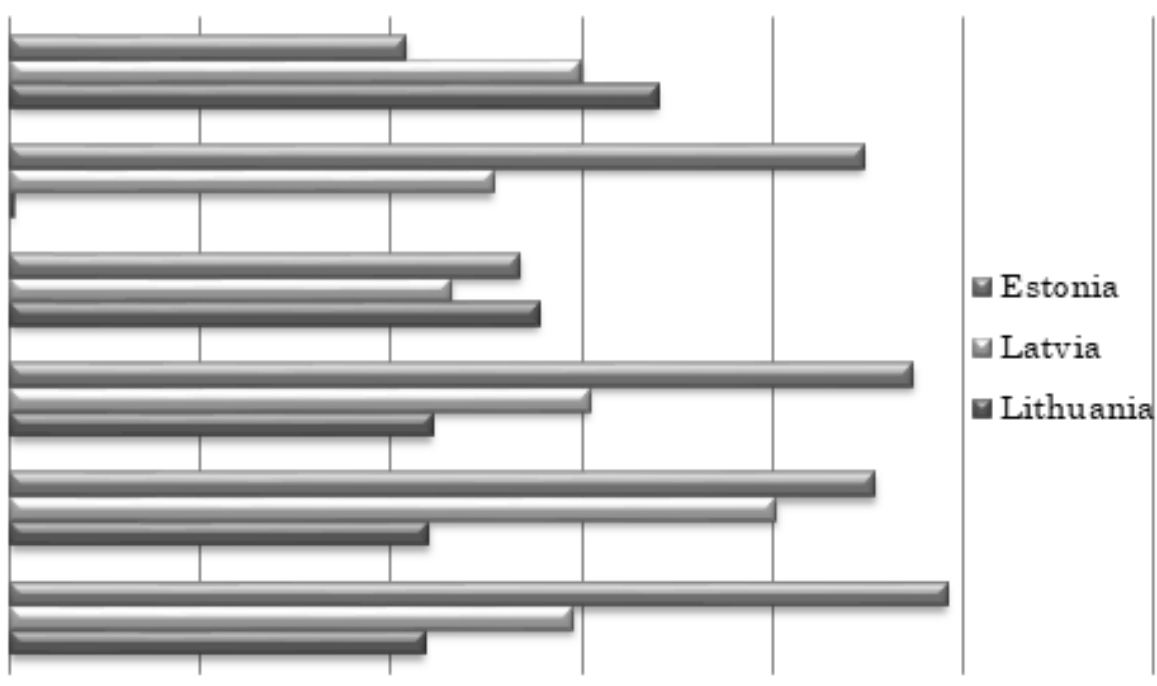

Fig. 1 Provisional CIS 2016 vs. CIS 2014 (=100), the Baltic States Source: EIS 2018

an entrepreneurial country is an opportunity to be tapped. Branding this concept can help this relatively small area to stand out in the Nordic area and the wider Baltic Sea and global arena". The Baltic States are far behind EU average in many significant indicators. For instance, Employment in high and medium high-tech, Employment in knowledge-intensive services and FDI net flows can be counted as some significant indicators that the Baltic States are scoring below EU average (Table 1).

Human resources, intellectual assets, innovation friendly environment, investment, finance and support and attractive research systems, employment impact and sales impact are the most significant innovation dimensions. In Lithuania, linkages and innovation friendly environment are the strongest dimensions, however, employment and sales impact, and also attractive research systems are the weakest rings. In the case of Latvia, innovators and firm investments are the weakest dimensions. In Estonia, human resources, intellectual assets, innovation friendly environment are the strongest dimensions as opposed to the other Baltic States. Innovators and sales impacts have scored with the lowest performance (Table 2). 
56 The Impact of Human Resources on Innovation Activities in the Baltic States: Employment and Innovation Persistence

Table 1 Structural differences of the European Union and the Baltic States

\begin{tabular}{|c|c|c|c|c|}
\hline Indicators & European Union & Lithuania & Latvia & Estonia \\
\hline \multicolumn{5}{|l|}{ Performance and structure of the economy } \\
\hline GDP per capita (PPP) & 28,600 & 21,500 & 18,300 & 21,500 \\
\hline Average annual GDP growth (\%) & 2.2 & 3.1 & 3.4 & 3.4 \\
\hline Employment share Manufacturing (NACE C) (\%) & 12.5 & 15.3 & 13.4 & 18.6 \\
\hline - of which High and Medium high-tech (\%) & 37.2 & 13.3 & 12.3 & 19.9 \\
\hline Employment share Services (NACE G-N) (\%) & 41.6 & 39.5 & 41.7 & 39.3 \\
\hline - of which Knowledge intensive services (\%) & 35.0 & 23.7 & 28.3 & 30.6 \\
\hline Turnover share SMEs (\%) & 38.0 & 48.7 & 51.2 & 48.0 \\
\hline Turnover share large enterprises (\%) & 44.4 & 33.3 & 22.2 & 22.5 \\
\hline Foreign-controlled enterprises - share of value-added (\%) & 12.5 & 11.9 & 15.7 & 16.0 \\
\hline \multicolumn{5}{|l|}{ Business and entrepreneurship } \\
\hline Enterprise births (10+ employees) $(\%)$ & 1.5 & 2.3 & 2.0 & 0.9 \\
\hline Total Entrepreneurial Activity (TEA) (\%) & 6.6 & $\mathrm{n} / \mathrm{a}$ & 14.2 & 16.2 \\
\hline FDI net inflows (\% GDP) & 3.6 & 1.9 & 2.3 & 2.2 \\
\hline Top R\&D spending enterprises per 10 mln. population & 19.7 & 0.0 & 0.0 & 0.0 \\
\hline Buyer sophistication (1 to 7 best) & 3.7 & 3.2 & 2.9 & 3.5 \\
\hline \multicolumn{5}{|l|}{ Governance and policy framework } \\
\hline Easy of starting a business ( 0 to 100 best) & 76.9 & 78.3 & 79.3 & 80.8 \\
\hline Basic-school entrepren. education and training ( 1 to 5 best) & 1.9 & $\mathrm{n} / \mathrm{a}$ & 2.4 & 2.8 \\
\hline Govt. procurement of advanced tech products ( 1 to 7 best) & 3.5 & 3.0 & 3.1 & 3.9 \\
\hline Rule of law (-2.5 to 2.5 best) & 1.2 & 1.0 & 0.9 & 1.3 \\
\hline \multicolumn{5}{|l|}{ Demography } \\
\hline Population size (millions) & 510.1 & 2.9 & 2.0 & 1.3 \\
\hline Average annual population growth (\%) & 0.3 & -1.3 & -0.9 & 0.0 \\
\hline Population density (inhabitants $/ \mathrm{km}^{2}$ ) & 117.1 & 46.3 & 31.6 & 30.3 \\
\hline
\end{tabular}

Source: EIS 2018 
Table 2: Innovation performance of the Baltic States

\begin{tabular}{|c|c|c|c|c|c|c|c|c|c|}
\hline & \multicolumn{3}{|c|}{ Lithuania } & \multicolumn{3}{|l|}{ Latvia } & \multicolumn{3}{|c|}{ Estonia } \\
\hline & \multicolumn{2}{|c|}{$\begin{array}{l}\text { Performance } \\
\text { relative to EU } \\
2010 \text { in }\end{array}$} & \multirow{2}{*}{$\begin{array}{l}\text { Relative } \\
\text { to EU } \\
2017 \text { in } \\
2017\end{array}$} & \multicolumn{2}{|c|}{$\begin{array}{l}\text { Performance } \\
\text { relative to EU } \\
2010 \text { in }\end{array}$} & \multirow{2}{*}{$\begin{array}{l}\text { Relative } \\
\text { to EU } \\
2017 \text { in } \\
2017\end{array}$} & \multicolumn{2}{|c|}{$\begin{array}{l}\text { Performance } \\
\text { relative to EU } \\
2010 \text { in }\end{array}$} & \multirow{2}{*}{$\begin{array}{l}\text { Relative } \\
\text { to EU } \\
2017 \text { in } \\
2017\end{array}$} \\
\hline & 2010 & 2017 & & 2010 & 2017 & & 2010 & 2017 & \\
\hline $\begin{array}{l}\text { SUMMARY } \\
\text { INNOVATION } \\
\text { INDEX }\end{array}$ & 55.1 & 75.3 & 71.1 & 48.2 & 59.8 & 56.6 & 86.4 & 83.2 & 78.6 \\
\hline Human resources & 106.9 & 115.5 & 96.8 & 64.7 & 79.8 & 66.8 & 93.3 & 123.9 & 103.8 \\
\hline $\begin{array}{l}\text { New doctoral } \\
\text { graduates }\end{array}$ & 61.5 & 51.1 & 36.7 & 30.8 & 38.8 & 27.9 & 53.8 & 67.9 & 48.7 \\
\hline $\begin{array}{l}\text { Population with } \\
\text { tertiary education }\end{array}$ & 214.9 & 237.3 & 209.2 & 116.4 & 132.8 & 117.1 & 125.4 & 144.0 & 127.0 \\
\hline Lifelong learning & 34.4 & 50.5 & 49.0 & 44.8 & 66.7 & 65.3 & 103.1 & 167.7 & 164.3 \\
\hline $\begin{array}{l}\text { Attractive research } \\
\text { systems }\end{array}$ & 32.0 & 39.5 & 34.8 & 12.6 & 55.8 & 49.1 & 59.6 & 101.8 & 89.5 \\
\hline $\begin{array}{l}\text { International } \\
\text { scientific } \\
\text { co-publications }\end{array}$ & 48.2 & 139.6 & 85.8 & 20.8 & 92.9 & 57.1 & 175.6 & 356.1 & 218.9 \\
\hline $\begin{array}{l}\text { Most cited } \\
\text { publications }\end{array}$ & 47.9 & 29.8 & 28.9 & 17.8 & 52.3 & 50.4 & 58.1 & 76.4 & 73.6 \\
\hline $\begin{array}{l}\text { Foreign doctorate } \\
\text { students }\end{array}$ & 3.8 & 18.8 & 17.0 & 2.3 & 47.9 & 43.2 & 21.7 & 50.4 & 45.5 \\
\hline $\begin{array}{l}\text { Innovation-friendly } \\
\text { environment }\end{array}$ & 103.3 & 164.5 & 123.0 & 116.7 & 141.2 & 105.5 & 90.3 & 138.9 & 103.8 \\
\hline
\end{tabular}


58 The Impact of Human Resources on Innovation Activities in the Baltic States: Employment and Innovation Persistence

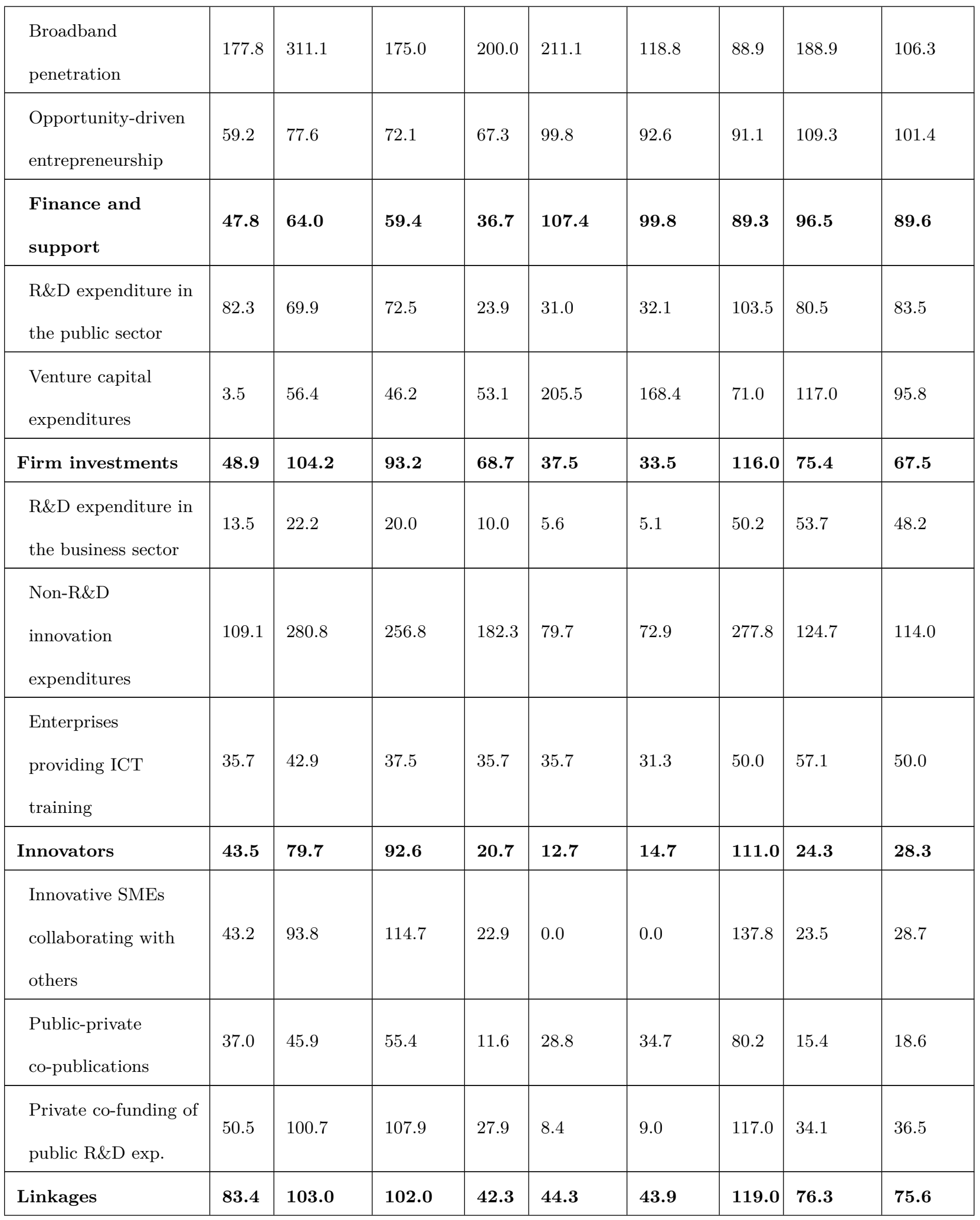




\begin{tabular}{|c|c|c|c|c|c|c|c|c|c|}
\hline $\begin{array}{l}\text { Innovative SMEs } \\
\text { collaborating with } \\
\text { others }\end{array}$ & 68.5 & 140.3 & 139.6 & 20.9 & 15.8 & 15.7 & 211.5 & 95.9 & 95.4 \\
\hline $\begin{array}{l}\text { Public-private } \\
\text { co-publications }\end{array}$ & 46.3 & 31.0 & 30.7 & 21.7 & 16.0 & 15.8 & 79.7 & 51.5 & 51.0 \\
\hline $\begin{array}{l}\text { Private co-funding of } \\
\text { public R\&D exp. }\end{array}$ & 139.2 & 144.0 & 142.0 & 86.4 & 104.3 & 102.8 & 68.2 & 83.6 & 82.4 \\
\hline Intellectual assets & 25.7 & 51.5 & 51.0 & 60.8 & 48.8 & 48.4 & 68.2 & 111.6 & 110.6 \\
\hline $\begin{array}{l}\text { PCT patent } \\
\text { applications }\end{array}$ & 14.8 & 21.8 & 22.8 & 20.4 & 22.3 & 23.3 & 51.0 & 27.3 & 28.4 \\
\hline $\begin{array}{l}\text { Trademark } \\
\text { applications }\end{array}$ & 56.1 & 107.5 & 95.1 & 105.6 & 112.0 & 99.1 & 117.7 & 196.3 & 173.7 \\
\hline Design applications & 13.0 & 37.2 & 38.5 & 64.9 & 26.1 & 27.0 & 47.0 & 127.0 & 131.6 \\
\hline $\begin{array}{l}\text { Employment } \\
\text { impacts }\end{array}$ & 62.2 & 39.6 & 39.3 & 51.6 & 94.1 & 93.6 & 55.5 & 74.9 & 74.5 \\
\hline $\begin{array}{l}\text { Employment in } \\
\text { knowledge-intensive } \\
\text { activities }\end{array}$ & 31.2 & 51.9 & 47.1 & 44.2 & 83.1 & 75.3 & 61.0 & 101.3 & 91.8 \\
\hline $\begin{array}{l}\text { Employment } \\
\text { fast-growing } \\
\text { enterprises }\end{array}$ & 84.4 & 30.7 & 32.8 & 56.8 & 102.0 & 109.0 & 51.5 & 56.1 & 60.0 \\
\hline Sales impacts & 31.9 & 36.6 & 35.1 & 45.1 & 46.3 & 44.4 & 59.8 & 65.4 & 62.8 \\
\hline $\begin{array}{l}\text { Medium and high } \\
\text { tech product exports }\end{array}$ & 36.0 & 49.6 & 46.8 & 31.8 & 43.3 & 40.9 & 48.1 & 61.9 & 58.5 \\
\hline $\begin{array}{l}\text { Knowledge-intensive } \\
\text { services exports }\end{array}$ & 0.3 & 8.7 & 8.3 & 74.1 & 70.6 & 67.3 & 62.9 & 62.8 & 59.9 \\
\hline
\end{tabular}




\begin{tabular}{|l|l|l|l|l|l|l|l|l|l|}
\hline $\begin{array}{l}\text { Sales of } \\
\text { new-to-market/firm } \\
\text { innovations }\end{array}$ & 63.7 & 53.7 & 53.1 & 27.1 & 21.4 & 21.2 & 70.0 & 72.6 & 71.9 \\
\hline
\end{tabular}

Source: EIS 2018.

\section{Conclusions}

In recent decades, a large number of empirical researches have studied on the nexus between innovation, job creation and employment. Based on studied literature review, the indeterminate nature of the impact of innovation on job creation and employment appears when companies launch new products onto the market and/or achieve new production or services processes. Whilst the benefits associated with innovations of these types are numerous and indisputable, theoretical studies suggest. The conclusions drawn from studies about the impact of human resources on companies' innovation activities are as follows:

- The preference of an innovation strategy and path implies the use of an incentive based on employee participation in innovation activities, the use of appraisal systems and the use of broad internal career opportunities.

- The companies that adopt an innovation strategy are more likely to attract internal labor markets than external ones. The use of human resources management practices aimed at building a stable group of employees in the company, which can adopt ideas and various approaches to the internal issues in achieving innovations that also can lead participation in the adoption of decisions that affect their job performance - all this is more likely to create the conditions for new ideas that feed innovation.

The intensive population lose in the Baltic States is a barrier to the innovative firms. Even though there are some improvements in the innovation performance of the Baltic States, this synergy could be more effective in case of the effective usage of human resources. Job creation would lead to stopping the outflow of human resources from the Baltic States and it would even reverse the current situation and attract more inflow migration.

\section{References}

Antonelli, C. (1997). “The Economics of Path-Dependence in Industrial Organization.” International Journal of Industrial Organization, Vol. 15, pp. 643-675.

Antonelli, C., Crespi, F. and Scellato, G. (2012). "Inside Innovation Persistence: New Evidence from Italian 
Micro-data." Structural Change and Economic Dynamics, Vol. 23, pp. 341-353.

Beugelsdijk, S. (2008). "Strategic Human Resource Practices and Product Innovation." Organization Studies, Vol. 29, Issue 6, pp. 821-847.

Bianchini, S. and Pallegrino, G. (2017). Innovation Persistence and Employment Dynamics, IEB Working Paper, Vol. 3. Spain: Barcelona.

Blundell, R. and Bond, S. (1998). "Initial Conditions and Moment Restrictions in Dynamic Panel Data Models." Journal of Econometrics, Vol. 87, pp. 115-143.

Cefis, E. (2003). "Is There Persistence in Innovative Activities?" International Journal of Industrial Organization, Vol. 21, pp. 489-515.

Chen, C.-J. and Huang, J.-W. (2009). "Strategic Human Resource Practices and Innovation Performance: The Mediating Role of Knowledge Management Capacity." Journal of Business Research, Vol. 62, Issue 1, pp. 104-114.

Dalota, M. and Perju, A. (2010). "Human Resources Management and the Company's Innovation." Romanian Economic Business Review, Vol. 5, Issue 4, pp. 122-131. Romania.

De Leede, J. and Looise, J.C. (2005). "Innovation and HRM: Towards an Integrated Framework." Creativity and Innovation Management, Vol. 14, Issue 2, pp. 108-117.

De Winne, S. and Sels, L. (2010). "Interrelationships between Human Capital, HRM and Innovation in Belgian Start-ups Aiming at an Innovation Strategy." International Journal of Human Resource Management, Vol. 21, Issue 11, pp. 1863-1883.

Deschryvere, M. (2014). "R\&D, Firm Growth and the Role of Innovation Persistence: An Analysis of Finnish SMEs and Large Firms." Small Business Economics, Vol. 43, pp. 767-785.

Dosi, G., Faillo, M. and Marengo, L. (2008). "Organizational Capabilities, Patterns of Knowledge Accumulation and Governance Structures in Business Firms: An Introduction." Organization Studies, Vol. 29, pp. 1165-1185.

Dosi, G. and Nelson, R. (2010). "Technical Change and Industrial Dynamics as Evolutionary Processes." Handbook of the Economics of Innovation, Vol. 1, pp. 51-127.

European Innovation Scoreboard (2018). Retrieved on October 3, 2019 from https://ec.europa.eu/ growth/industry/innovation/facts-figures/scoreboards_en.

Eurostat (2015). Smarter, Greener, More Inclusive? Indicators to Support the Europe 2020 Strategy. Eurostat Statistic Book.

Florida, R. (2004). Response to Edward Glaeser's Review of The Rise of the Creative Class. Retrieved on October 3, 2019 from http://creativeclass.com/rfcgdb/articles/ResponsetoGlaeser.pdf.

Gupta, A. K., Smith, K. G. and Shalley, C. E. (2006). "The Interplay between Exploration and Exploitation." Academy of Management Journal, Vol. 49, Issue 4, pp. 693-706.

Laursen, K., Masciarelli, F. and Prencipe, A. (2012). "Regions Matter: How Localized Social Capital Affects Innovation and External Knowledge Acquisition." Organization Science, Vol. 23, Issue 1, pp. 177193.

Li, Y., Vanhaverbeke, W. and Schoenmakers, W. (2008). "Exploration and Exploitation in Innovation: Re- 
framing the Interpretation." Creativity and Innovation Management, Vol. 17, Issue 2, pp. 107-126.

Malerba, F. (2007). "Innovation and the Dynamics and Evolution of Industries: Progress and Challenges." International Journal of Industrial Organization, Vol. 25, pp.675-699.

March, J. G. (1991). "Exploration and Exploitation in Organizational Learning." Organization Science, Vol. 2, Issue 1, pp. 71-87.

Nauwelaers, C., Maguire, C. K. and Marsan G. A. (2013). OECD Regional Development Working Papers 2013/19. The Case of Helsinki-Tallinn (FInland-Estonia) - Regions and Innovation: Collaborating Across Borders. Retrieved on September 30, 2019 from https ://www.oecd.org/cfe/regional-policy/ publicationsdocuments/Helsinki-Tallinn.pdf .

Nonaka, I. and Takeuchi, H. (1995). The Knowledge-Creating Company: How Japanese Companies Create the Dynamics of Innovation. New York: Oxford Press.

Raymond, W., Mohnen, P., Palm, F. and Van Der Loeff, S. (2010). Persistence of Innovation in Dutch Manufacturing: Is it Spurious? The Review of Economics and Statistics, Vol. 92, pp. 495-504.

Trading Economics. Economic Indicators of Estonia. Retrieved from https://tradingeconomics.com/ Estonia/indicators.

Trading Economics. Economic Indicators of Latvia. Retrieved from https://tradingeconomics.com/ latvia/indicators.

Trading Economics. Economic Indicators of Lithuania. Retrieved from https : //tradingeconomics . com/ lithuania/indicators.

Vivarelli, M. (2014). "Innovation, Employment and Skills in Advanced and Developing Countries: A survey of Economic Literature." Journal of Economic Issues, Vol. 48, pp. 123-154.

Wright, P. M. and McMahan, G. C. (2011). "Exploring Human Capital: Putting Human back into Strategic HRM.” Human Resource Management, Vol. 21, Issue 2, pp. 93-104. 